Research paper

\title{
Dual-tail arylsulfone-based benzenesulfonamides differently match the hydrophobic and hydrophilic halves of human carbonic anhydrases active sites: Selective inhibitors for the tumor-associated hCA IX isoform
}

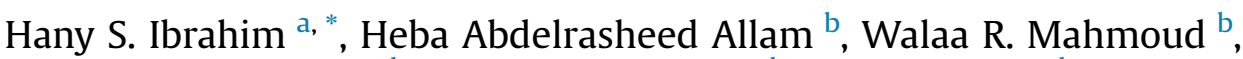 \\ Alessandro Bonardi c, d, Alessio Nocentini ${ }^{c, d}$, Paola Gratteri ${ }^{\mathrm{d}}$, Eslam S. Ibrahim ${ }^{\mathrm{e}}$, \\ Hatem A. Abdel-Aziz ${ }^{\text {, }}$ Claudiu T. Supuran ${ }^{\text {c, }}{ }^{* *}$ \\ ${ }^{a}$ Department of Pharmaceutical Chemistry, Faculty of Pharmacy, Egyptian Russian University, Badr City, Cairo, 11829, Egypt \\ b Department of Pharmaceutical Chemistry, Faculty of Pharmacy, Cairo University, Cairo, 11562, Egypt \\ ${ }^{\mathrm{c}}$ Università degli Studi di Firenze, Department NEUROFARBA - Pharmaceutical and Nutraceutical section, University of Firenze, via Ugo Schiff 6, I-50019, \\ Sesto Fiorentino, Firenze, Italy \\ d Department of NEUROFARBA, Section of Pharmaceutical and Nutraceutical Sciences, Laboratory of Molecular Modeling Cheminformatics \& QSAR, \\ University of Florence, Polo Scientifico, Via U. Schiff 6, 50019, Sesto Fiorentino, Firenze, Italy \\ e Department of Microbiology and Immunology, Faculty of Pharmacy, Cairo University, Cairo, 11562, Egypt \\ ${ }^{\mathrm{f}}$ Department of Applied Organic Chemistry, National Research Center, Dokki, Giza, P.O. Box 12622, Egypt
}

\section{A R T I C L E I N F O}

\section{Article history:}

Received 17 February 2018

Received in revised form

18 March 2018

Accepted 8 April 2018

Available online 10 April 2018

\section{Keywords:}

Carbonic anhydrase

Zinc-binding group

hCA IX

Dual-tails

Selectivity

Anti-tumor

\begin{abstract}
A B S T R A C T
The synthesis and characterization of two new sets of arylsulfonehydrazone benzenesulfonamides (4a-4i with phenyl tail and $\mathbf{4 j - 4 q}$ with tolyl tail) are reported. The compounds were designed according to a dual-tails approach to modulate the interactions of the ligands portions at the outer rim of both hydrophobic and hydrophilic active site halves of human isoforms of carbonic anhydrase (CA, EC 4.2.1.1). The synthesized sulfonamides were evaluated in vitro for their inhibitory activity against the following human (h) isoforms, hCA I, II, IV and IX. With the latter being a validated anticancer drug target and a marker of tumor hypoxia, attractive results arose from the Compounds' inhibitory screening in terms of potency and selectivity. Indeed, whereas the first subset of compounds $\mathbf{4 a - 4 i}$ exhibited great efficacy in inhibiting both the ubiquitous, off-target hCA II $\left(\mathrm{K}_{\mathrm{I}} \mathrm{S} 9.5-172.0 \mathrm{nM}\right)$ and hCA IX $\left(\mathrm{K}_{\mathrm{I}} \mathrm{s} 7.5-131.5 \mathrm{nM}\right)$, the second subset of tolyl-bearing derivatives $\mathbf{4 j - 4 q}$ were shown to possess a selective hCA IX inhibitory action over isoforms I, II and IV. The most selective compounds $\mathbf{4 l}$ and $\mathbf{4 n}$ were further screened for their in vitro cytotoxic activity against MCF-7 and MDA-MB-231 cancer cell lines under hypoxic conditions. The selective IX/II inhibitory trend of $\mathbf{4 j - 4 q}$ compared to those of compounds $\mathbf{4 a - 4 i}$ was unveiled by docking studies. Further exploration of these molecules could be useful for the development of novel antitumor agents with a selective CA inhibitory mechanism.
\end{abstract}

() 2018 Elsevier Masson SAS. All rights reserved.

\section{Introduction}

Human carbonic anhydrase (CA, EC 4.2.1.1) IX is a membranebound enzyme whose expression is strongly induced by hypoxia,

\footnotetext{
* Corresponding author.

** Corresponding author.

E-mail addresses: Hany.s.ibrahim@gmail.com (H.S. Ibrahim), claudiu.supuran@ unifi.it (C.T. Supuran).
}

a condition featured by low level of oxygen occurring in different types of solid tumors, such as glioma, breast cancer and colon carcinoma [1-3]. The activity of the over-expressed hCA IX maintains a proper external $\mathrm{pH}$, supporting an acidic extracellular microenvironment suited for hypoxic tumor cells, thus regulating cell proliferation, adhesion, and malignant cell invasion [1]. hCA IX inhibition has been shown to be associated with a significant suppression of the growth of both primary tumors and metastases, recognizing such an isozyme as a validated anticancer drug target, marker of tumor hypoxia and prognostic factor for several types of 
cancers $[4,5]$. With its expression being limited in normal tissues, hCA IX has become an attractive target for the design of antineoplastic drugs [6]. Despite that acetazolamide (AAZ) and other sulfonamide CAIs were reported to slowdown tumor growth and to delay tumor development, the lack of selectivity of sulfonamidelike CAIs against the different human ( $h$ ) isozymes is the main issue that prevents a wider pharmaceutical application to date $[1,7,8]$. Typically, the sulfonamide moiety coordinates the $\mathrm{Zn}$ ion present within the hCAs active sites and establishes two additional hydrogen bonds with a residue nearby (Thr199). Such binding features are common among the active site architectures of all the 15 human isozymes, ${ }^{1}$ which belong to the $\alpha$-class (seven distinct genetic families have been identified so far, the $\alpha-, \beta-, \gamma-, \delta-, \zeta-. \eta-$ and $\theta$-CAs) $[8,9]$. The active site cavity of hCAs is divided into two very different environments: the first one is delimited by a cluster of hydrophobic amino acids, whereas the other one is lined with hydrophilic residues (Fig. 1) [8,9].

Different approaches have been employed to design sulfonamide CAIs that exceed the poor selectivity boundary, with the "tail approach" being the most efficient and exploited one (Fig. 1) $[4,10,11]$. It consists in appending different molecular moieties (tails) to the aromatic/heterocyclic ring bearing the zinc binding group, in order to modulate the interaction with the middle and the rim parts of the active site cavity, which is the most variable region among the 15 isoforms mentioned above. In this context, a ureidotailed sulfonamide CAI (SLC-0111) successfully completed Phase I clinical trials for the treatment of advanced, metastatic hypoxic tumors over-expressing hCA IX, being scheduled for Phase II trials later last year $[4,12]$.

In the present work, we apply a dual-tails approach to modulate the interactions of the ligands at the outer rim of both hydrophobic and hydrophilic regions, seeking for isoform-selective inhibition profiles. Dual-tails CAIs were previously reported by Tanpure et al. by applying the "Click approach" to combine glyosidic and phenyl portions onto a sulfonamide scaffold [13].

The herein designed compounds $4 \mathbf{4 a - q}$ possess a Zinc Binding Group (ZBG) of the benzenesulfonamide type and a highly flexible molecular structure of the methyl hydrazone type to enhance the probability of a proper orientation and contacts with both hydrophilic and hydrophobic halves of the active site. A sulfone group was incorporated to increase the binding to the hydrophilic part of the active site. The aromatic tail appended at the sulfone moiety is of the phenyl or tolyl type as shown in Fig. 1. On the other hand, the use of diverse hydrophobic substituents on the hydrazine-linked aromatic portion should ensure suited SAR exploration regarding the hydrophobic region. All of these designed compounds were synthesized, characterized and biologically tested against four relevant hCA isoforms (I, II, IV and IX). Furthermore, compounds with best hCA IX inhibition properties have been subjected to cytotoxic activity evaluation against two different cell lines expressing the tumorassociated isozyme.

\section{Results and discussion}

\subsection{Chemistry}

To obtain the target compounds 4a-q, variable 2-bromoacetyl aryl or heteroaryl derivatives (2a-k) were refluxed separately with sodium benzene sulfinate in ethanol obtaining different phenyl sulfones 3a-q [14]. Consequently, the intermediate compounds 3a-q were refluxed with 4-hydrazinobenzene sulfonamide $\mathrm{HCl}$ salt in ethanol and catalytic amount of acetic acid to afford the hydrazones 4a-q (Scheme 1). ${ }^{1} \mathrm{H}$ NMR of compounds $\mathbf{4 a - q}$ revealed the two protons of the active methylene group $\left(-\mathrm{SO}_{2} \mathrm{CH}_{2}-\right)$ which appeared as singlet at nearly $\delta=5.01 \mathrm{ppm}$. In addition, ${ }^{13} \mathrm{C}$ NMR confirmed this data by illustrating a peak for this carbon $\left(-\mathrm{SO}_{2} \mathrm{CH}_{2}-\right)$ at about $\delta=54.3 \mathrm{ppm}$. Peaks of $\mathrm{D}_{2} \mathrm{O}$ exchangeable protons were important in this analysis to confirm that the reaction was complete. ${ }^{1} \mathrm{H}$ NMR analysis of compound $4 \mathbf{i}$ was very interesting as it informed us that this compound presented in $Z$ and $E$ isomers by ratio (2:1) when this compound was dissolved in DMSO. Otherwise, all the synthesized compounds were expected to be found in one conformer in solid state, which is $\mathrm{Z}$ conformer analogous to the reported compounds [15-17].

\subsection{Biological evaluation}

\subsubsection{Carbonic anhydrase inhibition}

The CA inhibitory properties of sulfonamide derivatives $\mathbf{4 a - 4 q}$ against human isoforms CA I, II, IV and IX were measured using acetazolamide (AAZ) as standard inhibitor by a stopped flow $\mathrm{CO}_{2}$ hydrase assay [18]. The rational for the choice of these four isoforms is that the ubiquitous hCA I and II are the main off-target isoforms for the anticancer CAIs therapeutic application. Isoform hCA IV shares with hCA IX the extra-cellular localization and is a drug target for retinitis pigmentosa, stroke and inflammatory pathologies such as rheumatoid arthritis.

The following structure-activity relationship (SAR) were obtained from the inhibition data reported in Table 1 :

(i) The off-target isoform hCA I was moderately inhibited by sulfonamides $\mathbf{4 a - 4 q}$ herein reported with inhibition constants $\left(\mathrm{K}_{\mathrm{I}} \mathrm{s}\right)$ spanning in the high nanomolar-low micromolar range, between 272.1 and $3771.1 \mathrm{nM}$. Noteworthy, increasing steric hindrance on the hydrazone aromatic portion almost generally worsened the hCA I inhibitory efficacy of the reported series of dual-tails sulfonamides. As a matter of fact,

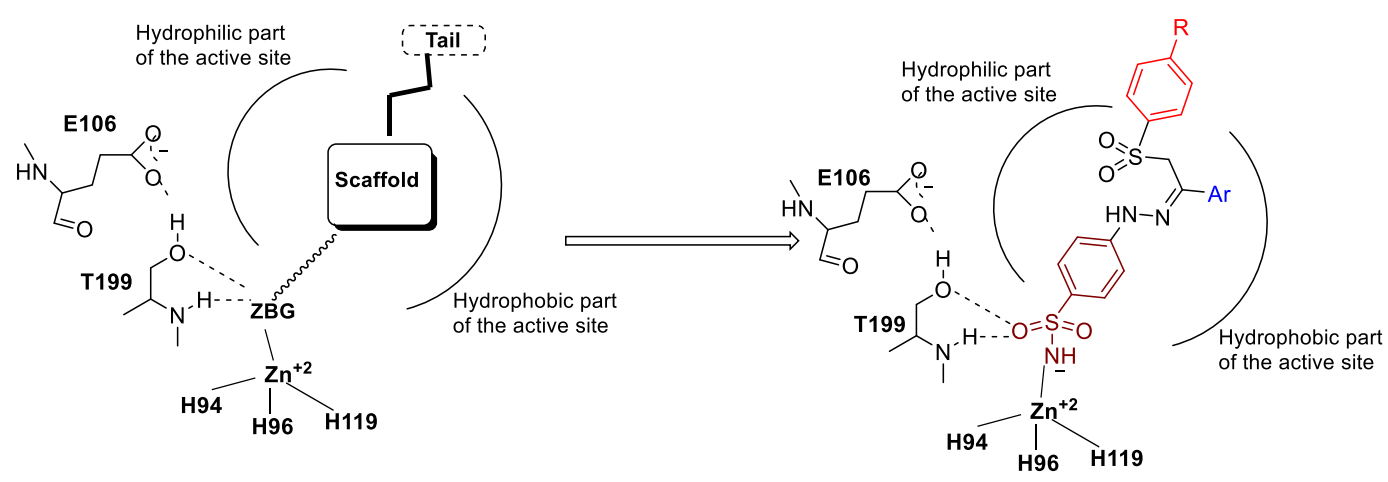

Fig. 1. Design approach to arylsulfone-based benzenesulfonamides (4a-4q). 
<smiles>[R]c1ccc(S(N)(=O)=O)cc1</smiles>

1a,b

2a-k<smiles>[R]c1ccc(S(=O)(=O)CC(=O)Br)cc1</smiles>

$$
\mathbf{R}=\mathrm{H}, \mathrm{CH}_{3}
$$

$$
\begin{aligned}
\mathbf{A r}= & \mathrm{C}_{6} \mathrm{H}_{5}, 4-\mathrm{FC}_{6} \mathrm{H}_{5}, 4-\mathrm{ClC}_{6} \mathrm{H}_{5} \\
& 4-\mathrm{BrC}_{6} \mathrm{H}_{5}, 4-\mathrm{CH}_{3} \mathrm{C}_{6} \mathrm{H}_{5}, 4-\mathrm{NO}_{2} \mathrm{C}_{6} \mathrm{H}_{5} \\
& 4-\mathrm{PhC}_{6} \mathrm{H}_{5}, \mathrm{C}_{10} \mathrm{H}_{9}, 2 \text {-furyl,2-benzofuryl }
\end{aligned}
$$

$$
\downarrow
$$<smiles>[R]c1ccc(S(=O)(=O)C/C(Br)=N\Nc2ccc(S(N)(=O)=O)cc2)cc1</smiles>
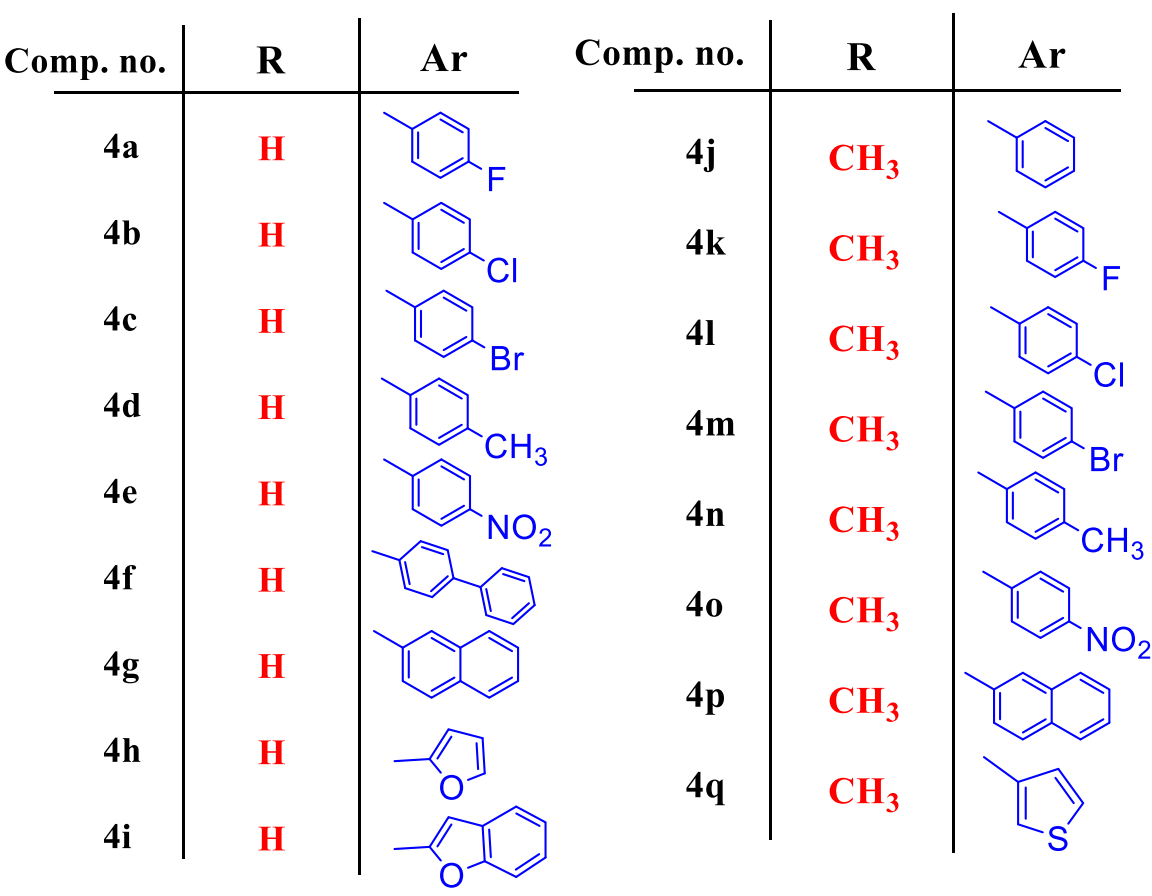

\section{$4 a-q$}

Scheme 1. Synthetic scheme for compounds 4a-p. Reagents and conditions: (i) EtOH/reflux for 6 h; (ii) $4-\mathrm{NH}_{2} \mathrm{NHC}_{6} \mathrm{H}_{5} \mathrm{SO}_{2} \mathrm{NH} \mathrm{H}_{2} \cdot \mathrm{HCl} / \mathrm{EtOH} \mathrm{CH}{ }_{3} \mathrm{COOH} / \mathrm{reflux}$ for $1 \mathrm{~h}$.

the $p-\mathrm{NO}_{2}, p$-phenyl and 2-naphthyl derivatives $\mathbf{4 e - 4 g}$ and 4o-4p arose as the least hCA I inhibitors herein reported with $\mathrm{K}_{\mathrm{I}} \mathrm{S}$ in the range $\left.1924.4-3771.1 \mathrm{nM}\right)$.

(ii) The physiologically dominant isoform hCA II was interestingly inhibited by the investigated compounds with $\mathrm{K}_{\mathrm{I}}$ values ranging between 9.5 and $791.1 \mathrm{nM}$. Indeed, despite the generally efficient hCA II inhibitory efficiency ascribable to $\mathbf{4 a - 4 q}$, an attractive trend can be deduced analyzing the data in Table 1. The incorporation of the methyl group in the para position of the sulfone-linked phenyl ring reduce the inhibitory efficacy of each tolyl derivative ( $\left.\mathrm{K}_{\mathrm{I}} \mathrm{S} 9.5-172.0 \mathrm{nM}\right)$ in comparison to the unsubstituted analogue $\left(\mathrm{K}_{\mathrm{I}} \mathrm{S}\right.$ 199.6-791.1 nM) seven-to twentyone-fold. Of note, the best hCA II inhibitory activity was ascribed to the $p$-F derivative 4a, with this latter being as potent as the standard AAZ.

(iii) The membrane-associated hCA IV was the least one inhibited by the dual-tails inhibitors herein reported, with $\mathrm{K}_{\mathrm{I}} \mathrm{S}$ spanning in the low micromolar range ( $\left.\mathrm{K}_{\mathrm{I}} \mathrm{S} 709.5-4166.8 \mathrm{nM}\right)$. Incorporation of the nitro group on the hydrazone-aromatic portion (4e and $\mathbf{4 0}$ ) or the substitution of this latter with a heterocycle of the furan (4h) or thiophene (4q) type heightened the relative compounds potency to a submicromolar range (709.5-912.0 nM).

(iv) The target tumor-associated isoform hCA IX was undeniably the most affected one amongst those herein considered. Considering the inhibition trend arose for isoform II, it immediately stands out from the inhibition data reported in Table 1, that all reported sulfonamides inhibit the transmembrane isoform in the low-nanomolar ( $\mathrm{K}_{\mathrm{I}} \mathrm{S}$ spanning in the range $5.3-131.5 \mathrm{nM}$ ), independently from the presence of a methyl group on the sulfone-linked phenyl ring. As a result, it could be hypothesized the likely presence of a pocket in hCA IX binding cavity, which can accommodate the methyl group, with unfavorable interactions conversely taking place within the hCA II active site. Noteworthy, the $p$ $\mathrm{Cl}, p-\mathrm{CH}_{3}$ and 2-naphthyl derivatives $(41,4 n$ and $4 \mathbf{p})$ within the methyl substituted subset acted as the most potent hCA IX inhibitors ( $\mathrm{K}_{\mathrm{I}} \mathrm{s}$ spanning in the range 5.3-15.3 nM) as well as the $p$-F derivative $4 a$ devoid of the methyl group ( $\mathrm{K}_{\mathrm{I}}$ of $7.5 \mathrm{nM})$. 
Table 1

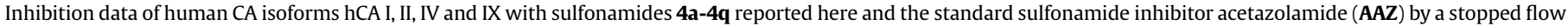
$\mathrm{CO}_{2}$ hydrase assay [18].

\begin{tabular}{|c|c|c|c|c|c|c|c|}
\hline \multirow[t]{2}{*}{ Compound } & \multicolumn{4}{|c|}{$\mathrm{K}_{\mathrm{I}}(\mathrm{nM})^{\mathrm{a}}$} & \multicolumn{3}{|l|}{$\mathrm{SI}^{\mathrm{b}}$} \\
\hline & hCA I & hCA II & hCA IV & hCA IX & (hCA I/IX) & (hCA II/IX) & (hCA IV/IX) \\
\hline $4 a$ & 272.1 & 9.5 & 1692.1 & 7.5 & 36.28 & 1.27 & 225.61 \\
\hline $4 b$ & 517.5 & 48.6 & 2577.4 & 34.8 & 14.87 & 1.40 & 74.06 \\
\hline $4 c$ & 894.2 & 53.3 & 2255.5 & 61.2 & 14.61 & 0.87 & 36.85 \\
\hline $4 d$ & 747.3 & 38.9 & 2813.9 & 36.5 & 20.47 & 1.07 & 77.09 \\
\hline $4 e$ & 1924.4 & 59.7 & 912.0 & 71.6 & 26.88 & 0.83 & 12.74 \\
\hline $4 f$ & 3133.7 & 172.0 & 4166.8 & 131.5 & 23.83 & 1.31 & 31.69 \\
\hline $4 \mathrm{~g}$ & 2847.2 & 65.7 & 3122.9 & 39.3 & 72.45 & 1.67 & 79.46 \\
\hline $4 h$ & 574.0 & 91.6 & 709.5 & 79.3 & 7.24 & 1.16 & 8.95 \\
\hline $4 i$ & 941.9 & 74.2 & 2887.8 & 69.1 & 13.63 & 1.07 & 41.79 \\
\hline $4 j$ & 567.6 & 234.0 & 3510.9 & 39.5 & 14.37 & 5.92 & 88.88 \\
\hline $4 k$ & 671.8 & 199.6 & 1350.2 & 27.6 & 24.34 & 7.23 & 48.92 \\
\hline 41 & 426.2 & 330.7 & 2009.2 & 8.7 & 48.99 & 38.01 & 230.94 \\
\hline $4 m$ & 915.7 & 354.8 & 2296.0 & 56.1 & 16.32 & 6.32 & 40.93 \\
\hline $4 n$ & 343.4 & 337.8 & 2721.6 & 5.3 & 64.79 & 63.74 & 513.51 \\
\hline 40 & 2273.7 & 791.1 & 795.0 & 79.2 & 28.71 & 9.99 & 10.04 \\
\hline $4 p$ & 3771.1 & 431.0 & 2646.9 & 15.3 & 246.48 & 28.17 & 173.00 \\
\hline $4 q$ & 905.6 & 291.8 & 839.2 & 56.3 & 16.09 & 5.18 & 14.91 \\
\hline AAZ & 250 & 12 & 74 & 25 & 10.00 & 0.48 & 2.96 \\
\hline
\end{tabular}

a Mean from 3 different assays, by a stopped flow technique (errors were in the range of $\pm 5-10 \%$ of the reported values).

b Selectivity as determined by the ratio of KI for hCA I, II or IV relative to hCA IX.

(v) As a result of the inhibitory trends extrapolated from the data in Table 1, interesting selectivity index (SI) arose for many derivatives herein reported. Indeed, all the tested compounds exhibited interesting selectivity towards hCA IX over hCA I, with compound 4p showing the higher I/IX selectivity herein reported with SI of 246.48. The results for all the tested compounds illustrated great selectivity against hCA IX over hCA IV, specially compounds $\mathbf{4 a}, \mathbf{4 l}, \mathbf{4 n}$ and $\mathbf{4 p}$, displaying SI of 225.61, 230.94, 513.51 and 173.00 , respectively. Finally, the methyl-devoid compounds displayed weak selectivity for hCA IX and over hCA II, whereas the SI markedly increased for the methyl-bearing subset, with compounds $\mathbf{4 l}$ and $\mathbf{4 n}$ possessing an interesting selectivity with SI 38.01 and 63.74, respectively (Table 1 ).

\subsubsection{In vitro cytotoxic assay}

The $p-\mathrm{Cl}$ and $p-\mathrm{CH}_{3}$-bearing compounds $\mathbf{4 1}$ and $\mathbf{4 n}$ within the tolyl-derivatives subset were further screened for their in vitro cytotoxic activity, owing to their unique potency and selectivity against the tumor-associated isoform hCA IX. Due to the recognized expression of the latter in breast malignancies [19,20], these compounds were screened against human breast adenocarcinoma cell line (MCF-7) and triple negative breast cancer cell line (MDA-MB231) using doxorubicin as a reference drug. The assay was run under hypoxic conditions of $5 \% \mathrm{CO}_{2}$ at $37{ }^{\circ} \mathrm{C}$ and the $\mathrm{IC}_{50}$ values in $\mu \mathrm{M}$ conc. of both compounds relative to doxorubicin is presented in Table 2. The results of the in vitro screening reported in Table 2 revealed that both compounds generally exhibited better

\section{Table 2}

$\mathrm{IC}_{50}$ values in $\mu \mathrm{M}$ of the in vitro cytotoxic inhibitory assay of compounds 41 and $4 \mathrm{n}$ under hypoxic conditions $\left(5 \% \mathrm{CO}_{2}\right)$ against MDA-MB-231 and MCF7 cell lines compared to doxorubicin.

\begin{tabular}{lll}
\hline \multirow{2}{*}{ Compound } & $\mathrm{IC}_{50}(\mu \mathrm{M})\left(5 \% \mathrm{CO}_{2}\right)$ & \\
\cline { 2 - 3 } & $\mathrm{MDA}-\mathrm{MB}-231$ & $\mathrm{MCF} 7$ \\
\hline $\mathbf{4 1}$ & $18.22 \pm 1.26$ & $3.9 \pm 0.21$ \\
$\mathbf{4 n}$ & $5.14 \pm 0.31$ & $2.33 \pm 0.14$ \\
Doxorubicin & $0.44 \pm 0.008$ & $0.37 \pm 0.02$ \\
\hline
\end{tabular}

cytotoxic activity against (MCF7) cell line than (MDA-MB-231). Compound $4 \mathbf{n}$, incorporating a dual-tolyl group in both tails, displayed better activity than the $p$-Cl derivative $\mathbf{4 l}$, with its activity being the half of that displayed by the reference drug doxorubicin.

\section{Molecular docking studies}

The binding modes of the herein reported compounds within the CA isozymes II and IX (PDB 5LJT [21] and 5FL4 [22], respectively; hCA IX residues are reported in brackets), were explored by docking and MM-GBSA simulations to unveil the relationships between structural features and the inhibition profiles. As expected by the in vitro results, in all docking solutions the benzenesulfonamide moiety is oriented deeply into the active sites of both the isoforms engaging two hydrogen bonds with the hCA II Thr199 (hCA IX Thr200). Its negatively charged nitrogen atom directly coordinated the zinc ion and the hydrophobic region lined by Val121, Val143 and Leu198 (hCA IX Val121, Val142 and Leu199) accommodated the phenyl ring. For all 4a-q derivatives, the tail appended at the benzenesulfonamide was similarly oriented in the two isoform active sites (Fig. 2). This orientation was primarily determined by the three-center $\mathrm{H}$-bond that the sulfone $\left(\mathrm{SO}_{2}\right)$ moiety engaged with the HE-Gln92 (HE-Gln92) and HD-Asn67 (HE-Gln71) atoms of the "hydrophilic" region of both active sites. Such a set of interactions strongly affected the positioning of the sulfone-linked aromatic portion of the ligands within the region lined by Ile91 (Leu91), Glu69 (Thr73) and Arg58 (Arg62), while the hydrazone aromatic portions accommodated in a wide hydrophobic area defined by Phe131, Val135, Leu204, Pro202, Pro201 and Leu198 (Val130, Leu 134, Ala205, Pro203, Pro202 and Leu199), with $\pi-\pi$ and $\pi$-alkyl interactions occurring between the aryl group and lipophilic side chains.

A key role is played by the hCA II/IX Glu69/Thr73 mutation in explaining the trend of inhibition profiles of derivatives $4 \mathbf{a}-\mathbf{4 i}$ and $\mathbf{4 j - 4 q}$ against trans-membrane hCA IX over the cytosolic hCA II (Fig. 3). Indeed, in hCA IX the para methyl-substituent on the terminal aromatic ring of $\mathbf{4 j} \mathbf{j} \mathbf{4 q}$ is oriented towards Thr73, with lipophilic interactions stabilizing the pose. Moreover, the less bulky Thr73 residue in hCA IX provides to the aromatic (un/)substituted tails more space than the Glu69 in the hCA II. As a matter of fact, the 
A

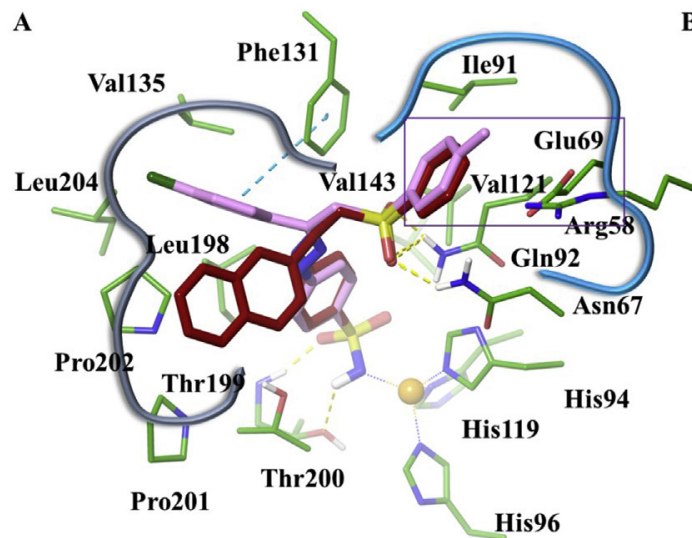

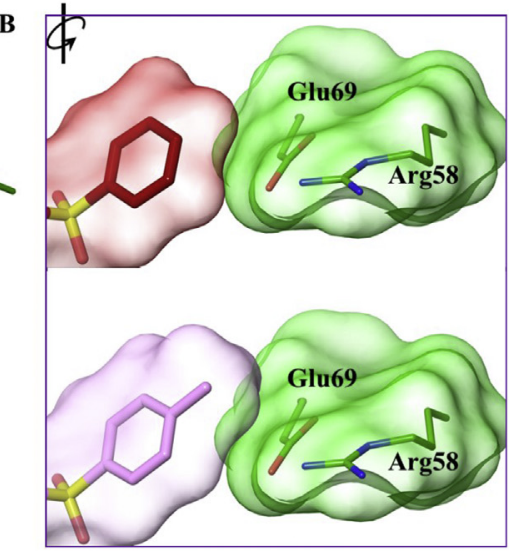

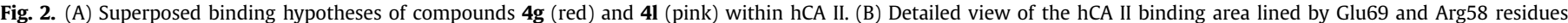

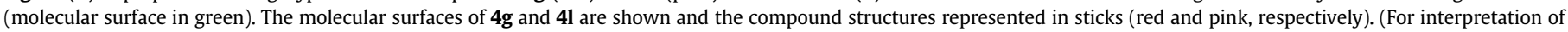
the references to colour in this figure legend, the reader is referred to the Web version of this article.)

$\mathbf{A}$

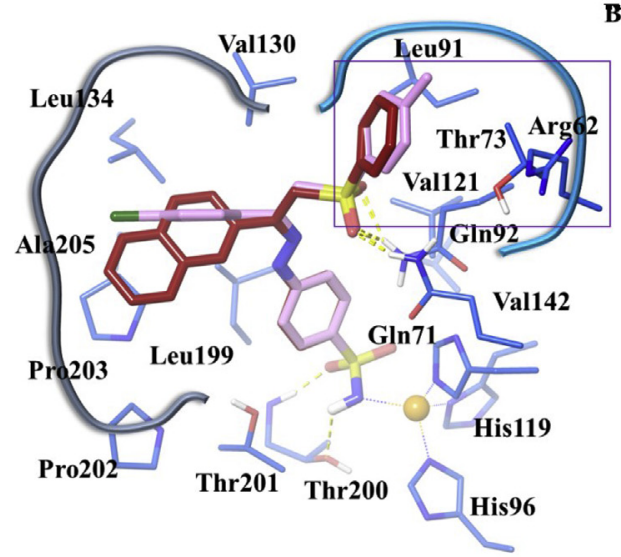

B

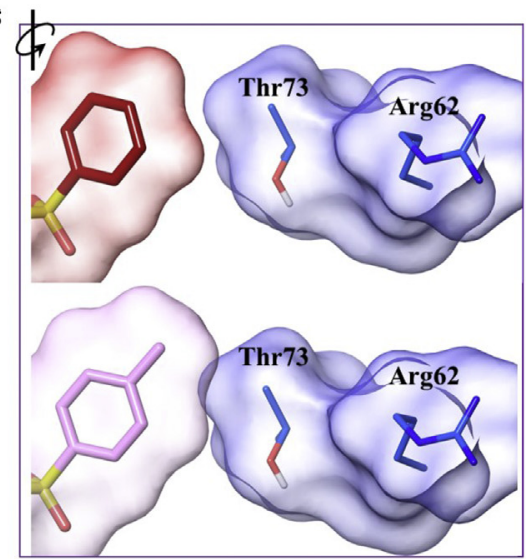

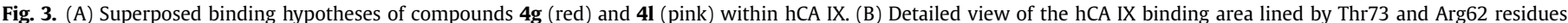

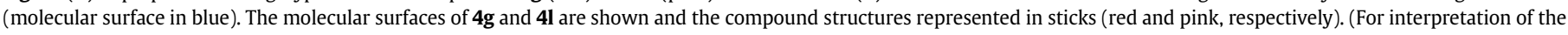
references to colour in this figure legend, the reader is referred to the Web version of this article.)

Glu69 - Arg58 charge interaction of the cytosolic isoform, constrains the position of the Glu69 and prevents an ideal shape complementarity of the substituted derivatives thus explaining the worst inhibition profile when compared with the unsubstitued ones.

It is reasonable to ascribe the potent and IX/II selective efficacy of compounds $41,4 n$ and $4 p$ (II/IX ratio of 38, 64 and 28) within the $p$-methyl-substituted subset to most favorable interactions taking place between the $p-\mathrm{Cl}, p-\mathrm{CH}_{3}$ and 2-naphthyl moieties, respectively, with the aforementioned lipophilic region of the tumorassociated isoform IX (Fig. 3).

\section{Conclusion}

In the present study, we reported the synthesis and characterization of two new series of arylsulfonehydrazone benzenesulfonamide (4a-4i and $\mathbf{4 j} \mathbf{j}-\mathbf{4 q})$. The compounds were designed according to a dual-tails approach to modulate the interactions of the ligands portions at the outer rim of both hydrophobic and hydrophilic active site halves of varied hCAs. The in vitro evaluation of the newly synthesized sulfonamides against hCA I, II, IV and IX furnished interesting results in terms of compounds inhibitory potency and selectivity. Indeed, whereas the first subset of compounds 4a-4i (unsubstituted phenyl-bearing) exhibited great efficacy in inhibiting both the ubiquitous, off-target hCA II $\left(\mathrm{K}_{\mathrm{I}} \mathrm{S}\right.$ 9.5-172.0 nM) and hCA IX $\left(K_{\mathrm{I}} \mathrm{S} 7.5-131.5 \mathrm{nM}\right)$, the tolyl-bearing derivatives $\mathbf{4 j - 4 q}$ were shown to possess a selective hCA IX inhibitory action over isoforms I, II and IV. In vitro cytotoxic activity evaluation of the most IX/II selective compounds $\mathbf{4 l}$ and $\mathbf{4 n}$ against MCF-7 and MDA-MB-231 cell lines under hypoxic conditions showed an efficient anti-proliferative action in the low micromolar range, with compound 4n showing a two-fold reduced efficacy than that shown by the reference drug doxorubicin. The study of the derivatives binding mode by modelling studies performed for all compounds with hCA II and IX shed light on the five-to sixty-fold II/IX selective inhibitory efficacy of $\mathbf{4 j - 4 q}$.

\section{Experimental}

\subsection{Chemistry}

\subsubsection{General}

Melting points were recorded on a Stuart SMP10 digital melting point apparatus and were uncorrected. Infrared (IR) Spectra were recorded as $\mathrm{KBr}$ disks using a Shimadzu FT-IR 8400S infrared spectrophotometer. Mass spectral data are given as $\mathrm{m} / \mathrm{z}$ (Intensity 
\%). NMR spectra were recorded on a Bruker Ascend 400/R ( ${ }^{1} \mathrm{H}: 400$, ${ }^{13} \mathrm{C}: 100 \mathrm{MHz}$ ) spectrometer. ${ }^{1} \mathrm{H}$ NMR spectra were run at $400 \mathrm{MHz}$ and ${ }^{13} \mathrm{C}$ spectra were run at $100 \mathrm{MHz}$ in deuterated dimethylsulfoxide (DMSO-d6). Chemical shifts are expressed in $\delta$ values (ppm) using the solvent peak as internal standard. All coupling constant $(J)$ values are given in hertz. The abbreviations used are as follows: $\mathrm{s}$, singlet; d, doublet; m, multiplet. Elemental analyses were carried out at the Regional Center for Mycology and Biotechnology, AlAzhar University, Egypt. Reaction courses and product mixtures were routinely monitored by Thin Layer Chromatography (TLC) on silica gel precoated F254 Merck plates. Unless otherwise noted, all solvents and reagents were commercially available and used without further purification. The analytical data of compounds 3aq were found as reported [14,23-28].

\subsubsection{General procedure for the preparation of compounds $\mathbf{4 a - q}$}

To a solution of the appropriate 1-aryl or heteroaryl-substituted 2-(aryl sulfonyl) ethanone $\mathbf{3 a - q}(1 \mathrm{mmol})$ in absolute ethanol in the presence of catalytic amount of glacial acetic acid, 4hydrazinobenzenesulfonamide $(0.187 \mathrm{~g}, 1 \mathrm{mmol})$ was added. The reaction mixture was heated under reflux. The solid formed was collected by filtration, dried and recrystallized from ethanol/DMF to afford compounds $\mathbf{4 a - q}$.

5.1.2.1. 4-[2-(1-(4-Fluorophenyl)-2-(phenylsulfonyl)ethylidene) hydrazinyl] benzenesulfonamide (4a). White crystals, (yield 60\%), $\mathrm{m}$. p. $251-252^{\circ} \mathrm{C}$; IR $\left(\mathrm{KBr}, \nu_{\max } / \mathrm{cm}^{-1}\right): 3361,3329,3271\left(\mathrm{NH}_{2} \& \mathrm{NH}\right)$, 1340 and $1145\left(\mathrm{SO}_{2}\right) ;{ }^{1} \mathrm{H}$ NMR (DMSO-d $\left.)_{6}\right) \delta$ ppm: $5.22(\mathrm{~s}, 2 \mathrm{H}$, $\left.-\mathrm{SO}_{2} \mathrm{CH}_{2}-\right), 7.09\left(\mathrm{~m}, 4 \mathrm{H}, \mathrm{Ar}-\mathrm{H}\right.$ and $\mathrm{D}_{2} \mathrm{O}$ exchangable, $\left.-\mathrm{SO}_{2} \mathrm{NH}_{2}\right), 7.19$ $(\mathrm{d}, J=8.8 \mathrm{~Hz}, 2 \mathrm{H}, \mathrm{Ar}-\mathrm{H}), 7.51(\mathrm{~m}, 1 \mathrm{H}, \mathrm{Ar}-\mathrm{H}), 7.59$ (m, 2H, Ar-H), 7.67 (d, $J=8.8 \mathrm{~Hz}, 2 \mathrm{H}, \operatorname{Ar}-\mathrm{H}$ ), 7.75 (t, $J=7.4 \mathrm{~Hz}, 2 \mathrm{H}, \operatorname{Ar}-\mathrm{H}$ ), 7.85 (d, $J=7.2 \mathrm{~Hz}, 2 \mathrm{H}, \mathrm{Ar}-\mathrm{H}), 10.08$ (s, $1 \mathrm{H}, \mathrm{D}_{2} \mathrm{O}$ exchangable, $\left.-\mathrm{NH}\right) ;{ }^{13} \mathrm{C} \mathrm{NMR}$ $\left(\right.$ DMSO- $\left.d_{6}\right) \delta$ ppm: $64.01\left(-\mathrm{CH}_{2}-\right), 112.70,115.45,120.53,123.19$, 127.72, 128.64, 129.43, 131.86, 134.50, 135.2, 139.40, 147.53; Anal. Calcd. for $\mathrm{C}_{20} \mathrm{H}_{18} \mathrm{FN}_{3} \mathrm{O}_{4} \mathrm{~S}_{2}$ (447.50): C, 53.68; H, 4.05; N, 9.39; Found C, 53.31; H, 4.23; N, 9.62.

5.1.2.2. 4-[2-(1-(4-Chlorophenyl)-2-(phenylsulfonyl)ethylidene) hydrazinyl] benzenesulfonamide (4b). White crystals, (yield $77 \%$ ), $\mathrm{m}$. p. $227-228^{\circ} \mathrm{C}$; IR $\left(\mathrm{KBr}, \nu_{\max } / \mathrm{cm}^{-1}\right): 3360,3325,3263\left(\mathrm{NH}_{2} \& \mathrm{NH}\right)$, 1330 and $1149\left(\mathrm{SO}_{2}\right) ;{ }^{1} \mathrm{H}$ NMR (DMSO-d 6 ) $\delta$ ppm: $5.21(\mathrm{~s}, 2 \mathrm{H}$, $\mathrm{SO}_{2} \mathrm{CH}_{2}$ ), $7.14\left(\mathrm{~s}, 2 \mathrm{H}, \mathrm{D}_{2} \mathrm{O}\right.$ exchangable, $\left.-\mathrm{SO}_{2} \mathrm{NH}_{2}\right), 7.20$ (d, $J=8 . \overline{8} \mathrm{~Hz}, 2 \mathrm{H}, \mathrm{Ar}-\mathrm{H}), 7.34$ (d, $J=8.7 \mathrm{~Hz}, 2 \mathrm{H}, \mathrm{Ar}-\mathrm{H}), 7.51(\mathrm{t}, J=7.5 \mathrm{~Hz}$, 2H, Ar-H), 7.59 (t, $J=7.5 \mathrm{~Hz}, 1 \mathrm{H}, \mathrm{Ar}-\mathrm{H}), 7.68$ (d, $J=8.8 \mathrm{~Hz}, 2 \mathrm{H}, \mathrm{Ar}-\mathrm{H}$ ), $7.74(\mathrm{~d}, J=8.7 \mathrm{~Hz}, 2 \mathrm{H}, \mathrm{Ar}-\mathrm{H}$ ), 7.85 (d, $J=7.5 \mathrm{~Hz}, 2 \mathrm{H}, \mathrm{Ar}-\mathrm{H}), 10.14$ (s, $1 \mathrm{H}, \mathrm{D}_{2} \mathrm{O}$ exchangable, $-\mathrm{NH}$ ); ${ }^{13} \mathrm{C}$ NMR (DMSO-d $\mathrm{d}_{6}$ ) $\delta$ ppm: 52.19 $\left(\mathrm{CH}_{2}\right), 112.81,127.72,128.21,128.48,128.65,129.45,131.43,133.03$, 134.52, 135.39, 136.53, 139.57, 147.49; Anal. Calcd. for $\mathrm{C}_{20} \mathrm{H}_{18} \mathrm{ClN}_{3} \mathrm{O}_{4} \mathrm{~S}_{2}$ (463.96): C, 51.77; H, 3.91; N, 9.06; Found C, 52.19; $\mathrm{H}, 4.08$; N, 8.87.

5.1.2.3. 4-[2-(1-(4-Bromophenyl)-2-(phenylsulfonyl)ethylidene) hydrazinyl] benzenesulfonamide (4c). White crystals, (yield 53\%), $\mathrm{m}$. p. $243-244{ }^{\circ} \mathrm{C}$; IR $\left(\mathrm{KBr}, \nu_{\max } / \mathrm{cm}^{-1}\right): 3363,3332,3248\left(\mathrm{NH}_{2} \& \mathrm{NH}\right)$, 1342 and $1145\left(\mathrm{SO}_{2}\right) ;{ }^{1} \mathrm{H}$ NMR (DMSO-d $\left.{ }_{6}\right) \delta \mathrm{ppm}$ : $5.21(\mathrm{~s}, 2 \mathrm{H}$, $\left.\mathrm{SO}_{2} \mathrm{CH}_{2}\right), 7.13\left(\mathrm{~s}, 2 \mathrm{H}, \mathrm{D}_{2} \mathrm{O}\right.$ exchangable, $\left.-\mathrm{SO}_{2} \mathrm{NH}_{2}\right), 7.19(\mathrm{~d}, J=8.8 \mathrm{~Hz}$, $2 \mathrm{H}, \overline{\mathrm{Ar}}-\mathrm{H}), 7.48(\mathrm{~d}, J=8.6 \mathrm{~Hz}, 2 \mathrm{H}, \mathrm{Ar}-\mathrm{H}), 7.53$ (d, $J=7.8 \mathrm{~Hz}, 2 \mathrm{H}, \mathrm{Ar}-\mathrm{H})$, $7.61(\mathrm{t}, J=7.3 \mathrm{~Hz}, 1 \mathrm{H}, \mathrm{Ar}-\mathrm{H}), 7.69$ (dd, $J=2.3 \mathrm{~Hz}, J=6.6 \mathrm{~Hz}, 4 \mathrm{H}, \mathrm{Ar}-$ $\mathrm{H}), 7.86(\mathrm{~d}, J=7.3 \mathrm{~Hz}, 2 \mathrm{H}, \mathrm{Ar}-\mathrm{H}), 10.14\left(\mathrm{~s}, 1 \mathrm{H}, \mathrm{D}_{2} \mathrm{O}\right.$ exchangable, -NH); ${ }^{13} \mathrm{C}$ NMR (DMSO-d $\left.d_{6}\right) \delta$ ppm: $52.07\left(\mathrm{CH}_{2}\right), 112.94,121.94$, 121.72, 128.34, 128.48, 129.60, 131.51, 134.55, 134.73, 136.57, 138.93, 147.47; Anal. Calcd. for $\mathrm{C}_{20} \mathrm{H}_{18} \mathrm{BrN}_{3} \mathrm{O}_{4} \mathrm{~S}_{2}$ (508.41): C, 47.25; H, 3.57; N, 8.27; Found C, 46.96; H, 3.74; N, 8.64.
5.1.2.4. 4-[2-(2-(Phenylsulfonyl)-1-(p-tolyl)ethylidene $)$ hydrazinyl] benzenesulfonamide (4d). Light brown crystals, (yield 73\%), m. p. 225-226 ${ }^{\circ} \mathrm{C}$; IR (KBr, $\left.\nu_{\max } / \mathrm{cm}^{-1}\right): 3363,3321,3267\left(\mathrm{NH}_{2} \& \mathrm{NH}\right)$, 1341 and $1149\left(\mathrm{SO}_{2}\right) ;{ }^{1} \mathrm{H}$ NMR (DMSO-d $\left.{ }_{6}\right) \delta \mathrm{ppm}: 2.30\left(\mathrm{~s}, 3 \mathrm{H},-\mathrm{CH}_{3}\right)$, $5.17\left(\mathrm{~s}, 2 \mathrm{H},-\mathrm{SO}_{2} \mathrm{CH}_{2}-\right), 7.11\left(\mathrm{~s}, 2 \mathrm{H}, \mathrm{D}_{2} \mathrm{O}\right.$ exchangable, $\left.-\mathrm{SO}_{2} \mathrm{NH}_{2}\right), \overline{7.18}$ $(\mathrm{d}, J=8.7 \mathrm{~Hz}, 2 \mathrm{H}, \overline{\mathrm{Ar}}-\mathrm{H}), 7.32(\mathrm{~d}, J=8.0 \mathrm{~Hz}, 2 \mathrm{H}, \mathrm{Ar}-\mathrm{H}), 7.61-7.68(\mathrm{~m}$, $3 \mathrm{H}, \mathrm{Ar}-\mathrm{H}), 7.73(\mathrm{~d}, J=7.4 \mathrm{~Hz}, 2 \mathrm{H}, \mathrm{Ar}-\mathrm{H}), 7.86(\mathrm{~d}, J=8.2 \mathrm{~Hz}, 2 \mathrm{H}, \mathrm{Ar}-\mathrm{H})$, $7.90(\mathrm{~d}, J=7.3 \mathrm{~Hz}, 2 \mathrm{H}, \mathrm{Ar}-\mathrm{H}), 9.99\left(\mathrm{~s}, 1 \mathrm{H}, \mathrm{D}_{2} \mathrm{O}\right.$ exchangable, $\left.-\mathrm{NH}\right)$; 13C NMR (DMSO-d $)_{6} \delta$ ppm: $21.22\left(\mathrm{CH}_{3}\right), 52.37\left(\mathrm{CH}_{2}\right), 112.61$, 126.50, 127.71, 128.62, 129.14, 129.40, 132.77, 134.44, 134.91, 134.96, 137.92, 139.71, 147.77; ESI MS $m / z: 443\left[\mathrm{M}^{+}, 444[\mathrm{M}+1]^{+}, 445\right.$ $[\mathrm{M}+2]^{+}$; Anal. Calcd. for $\mathrm{C}_{21} \mathrm{H}_{21} \mathrm{~N}_{3} \mathrm{O}_{4} \mathrm{~S}_{2}$ (443.54): C, 56.87; H, 4.77; N, 9.47; Found C, 57.14; H, 4.89; N, 9.70.

5.1.2.5. 4-[2-(1-(4-Nitrophenyl)-2-(phenylsulfonyl)ethylidene)hydrazinyl] benzenesulfonamide (4e). Yellow crystals, (yield 72\%), m. p. 230-232 ${ }^{\circ} \mathrm{C}$; IR $\left(\mathrm{KBr}, \nu_{\max } / \mathrm{cm}^{-1}\right): 3379,3313,3271\left(\mathrm{NH}_{2} \& \mathrm{NH}\right)$, 1334 and $1153\left(\mathrm{SO}_{2}\right) ;{ }^{1} \mathrm{H}$ NMR (DMSO- $\left.d_{6}\right) \delta$ ppm: $5.32(\mathrm{~s}, 2 \mathrm{H}$, $\left.\mathrm{SO}_{2} \mathrm{CH}_{2}\right), 7.18\left(\mathrm{~s}, 2 \mathrm{H}, \mathrm{D}_{2} \mathrm{O}\right.$ exchangable, $\left.-\mathrm{SO}_{2} \mathrm{NH}_{2}\right), 7.29(\mathrm{~d}, J=8.6 \mathrm{~Hz}$, $2 \mathrm{H}, \overline{\mathrm{Ar}}-\mathrm{H}), 7.52$ (t, $J=7.4 \mathrm{~Hz}, 2 \mathrm{H}, \mathrm{Ar}-\mathrm{H}), 7.60(\mathrm{t}, J=7.3 \mathrm{~Hz}, 1 \mathrm{H}, \mathrm{Ar}-\mathrm{H})$, 7.72 (d, $J=8.8 \mathrm{~Hz}, 2 \mathrm{H}, \mathrm{Ar}-\mathrm{H}), 7.87$ (d, $J=7.4 \mathrm{~Hz}, 2 \mathrm{H}, \mathrm{Ar}-\mathrm{H}), 7.99$ (d, $J=9.0 \mathrm{~Hz}, 2 \mathrm{H}, \mathrm{Ar}-\mathrm{H}), 8.13$ (d, $J=9.0 \mathrm{~Hz}, 2 \mathrm{H}, \operatorname{Ar}-\mathrm{H}), 10.48\left(\mathrm{~s}, 1 \mathrm{H}, \mathrm{D}_{2} \mathrm{O}\right.$ exchangable, $-\mathrm{NH}) ;{ }^{13} \mathrm{C}$ NMR (DMSO- $\left.d_{6}\right) \delta$ ppm: $52.07\left(\mathrm{CH}_{2}\right), 113.37$, $123.68,127.30,127.49,127.74,128.72,129.51,130.30,134.63,136.22$, 139.44, 144.05, 146.74, 147.04; Anal. Calcd. for $\mathrm{C}_{20} \mathrm{H}_{18} \mathrm{~N}_{4} \mathrm{O}_{6} \mathrm{~S}_{2}$ (474.51): C, 50.62; H, 3.82; N, 11.81; Found C, 50.87; H, 4.01; N, 12.17.

5.1.2.6. 4-[2-(1-([1,1'-Biphenyl]-4-yl)-2(phenylsulfonyl)ethylidene) hydrazinyl] benzenesulfonamide (4f). White crystals, (yield 70\%), $\mathrm{m}$. p. $220-221^{\circ} \mathrm{C}$; IR $\left(\mathrm{KBr}, \nu_{\max } / \mathrm{cm}^{-1}\right): 3383,3325,3271\left(\mathrm{NH}_{2} \& \mathrm{NH}\right)$, 1330 and $1145\left(\mathrm{SO}_{2}\right) ;{ }^{1} \mathrm{H}$ NMR (DMSO-d $\left.{ }_{6}\right) \delta \mathrm{ppm}: 5.27(\mathrm{~s}, 2 \mathrm{H}$, $\left.-\mathrm{SO}_{2} \mathrm{CH}_{2}-\right), 7.03(d, J=8.7 \mathrm{~Hz}, 1 \mathrm{H}, \mathrm{Ar}-\mathrm{H}), 7.14\left(\mathrm{~s}, 2 \mathrm{H}, \mathrm{D}_{2} \mathrm{O}\right.$ exchangable, - $\left.\mathrm{SO}_{2} \mathrm{NH}_{2}\right), 7.22(\mathrm{t}, J=9.0 \mathrm{~Hz}, 2 \mathrm{H}, \mathrm{Ar}-\mathrm{H}), 7.38(\mathrm{t}, J=7.3 \mathrm{~Hz}, 1 \mathrm{H}$, Ar-H), 7.47-7.59 (m, 4H, Ar-H), 7.61 (d, J=8.5 Hz, 2H, Ar-H), 7.71 (t, $J=9.0,4 \mathrm{H}, \mathrm{Ar}-\mathrm{H}), 7.84$ (d, $J=8.4 \mathrm{~Hz}, 2 \mathrm{H}, \mathrm{Ar}-\mathrm{H}), 7.90$ (d, $J=7.2 \mathrm{~Hz}$, $2 \mathrm{H}, \mathrm{Ar}-\mathrm{H}), 10.18$ (s, $1 \mathrm{H}, \mathrm{D}_{2} \mathrm{O}$ exchangable, $\left.-\mathrm{NH}\right) ;{ }^{13} \mathrm{C}$ NMR (DMSO- $d_{6}$ ) $\delta$ ppm: $52.30\left(\mathrm{CH}_{2}\right), 110.09,111.45,112.42,113.01,113.74,124.04$, 127.26, 127.40, 127.70, 128.75, 129.44, 129.53, 134.12, 136.62, 139.44, 147.14, 148.87; ESI MS $m / z$ : $521[\mathrm{M}+2]^{+}$; Anal. Calcd. for $\mathrm{C}_{26} \mathrm{H}_{23} \mathrm{~N}_{3} \mathrm{O}_{4} \mathrm{~S}_{2}$ (505.60): C, 61.76; H, 4.59; N, 8.31; Found C, 61.58; H, $4.72 ; \mathrm{N}, 8.57$.

5.1.2.7. 4-[2-(1-(Naphthalen-2-yl)-2-(phenylsulfonyl)ethylidene) hydrazinyl] benzenesulfonamide (4g). White crystals, (yield 62\%), $\mathrm{m}$. p. $230-231^{\circ} \mathrm{C}$; IR $\left(\mathrm{KBr}, \nu_{\max } / \mathrm{cm}^{-1}\right): 3360,3329,3263\left(\mathrm{NH}_{2} \& \mathrm{NH}\right)$, 1334 and $1149\left(\mathrm{SO}_{2}\right) ;{ }^{1} \mathrm{H}$ NMR (DMSO-d $\left.)_{6}\right) \delta \mathrm{ppm}$ : $5.35(\mathrm{~s}, 2 \mathrm{H}$, $\left.-\mathrm{SO}_{2} \mathrm{CH}_{2}-\right), 7.15\left(\mathrm{~s}, 2 \mathrm{H}, \mathrm{D}_{2} \mathrm{O}\right.$ exchangable, $\left.-\mathrm{SO}_{2} \mathrm{NH}_{2}\right), 7.27$ (d, $J=8.7 \mathrm{~Hz}, 1 \mathrm{H}, \mathrm{Ar}-\mathrm{H}), 7.35$ (s, 1H, Ar-H), 7.47-7.51 (m, 1H, Ar-H), 7.60 $(\mathrm{d}, J=9.0 \mathrm{~Hz}, 1 \mathrm{H}, \mathrm{Ar}-\mathrm{H}), 7.63-7.67(\mathrm{~m}, 2 \mathrm{H}, \mathrm{Ar}-\mathrm{H}), 7.70-7.72(\mathrm{~m}, 2 \mathrm{H}$, Ar-H), 7.83 (d, J=8.1 Hz, 1H, Ar-H), 7.90-7.95 (m, 3H, Ar-H), 8.00 (d, $J=8.6 \mathrm{~Hz}, 1 \mathrm{H}, \mathrm{Ar}-\mathrm{H}), 8.08(\mathrm{~d}, J=7.5 \mathrm{~Hz}, 1 \mathrm{H}, \mathrm{Ar}-\mathrm{H}), 8.73(\mathrm{~s}, 2 \mathrm{H}, \mathrm{Ar}-\mathrm{H})$, 10.18 (s, $1 \mathrm{H}, \mathrm{D}_{2} \mathrm{O}$ exchangable, $\left.-\mathrm{NH}\right) ;{ }^{13} \mathrm{C}$ NMR (DMSO- $\left.d_{6}\right) \delta \mathrm{ppm}$ : 52.22 $\left(\mathrm{CH}_{2}\right), 112.86,124.08,126.15,126.73,127.76,127.99,128.69$, 128.77, $129.39,132.50,132.98,133.15,134.44,134.94,135.27,139.68$, 147.66; Anal. Calcd. for $\mathrm{C}_{24} \mathrm{H}_{21} \mathrm{~N}_{3} \mathrm{O}_{4} \mathrm{~S}_{2}$ (479.57): C, 60.11; $\mathrm{H}, 4.41 ; \mathrm{N}$, 8.76; Found C, 60.43; H, 4.57; N, 8.98.

5.1.2.8. 4-[2-(1-(Furan-2-yl)-2-(phenylsulfonyl)ethylidene)hydrazinyl] benzenesulfonamide (4h). Brown crystals, (yield 67\%), m. p. 245-247 ${ }^{\circ} \mathrm{C}$; IR (KBr, $\left.\nu_{\max } / \mathrm{cm}^{-1}\right): 3367,3325,3275\left(\mathrm{NH}_{2} \& \mathrm{NH}\right)$, 1340 and $1145\left(\mathrm{SO}_{2}\right) ;{ }^{1} \mathrm{H}$ NMR (DMSO- $\left.d_{6}\right) \delta$ ppm: $5.04(\mathrm{~s}, 2 \mathrm{H}$, $\left.\mathrm{SO}_{2} \mathrm{CH}_{2^{-}}\right), 6.88(\mathrm{t}, J=4.2 \mathrm{~Hz}, 1 \mathrm{H}$, furan- $\mathrm{H}), 7.10(\mathrm{~d}, J=8.7 \mathrm{~Hz}, 2 \mathrm{H}, \mathrm{Ar}-$ $\mathrm{H}), 7.12\left(\mathrm{~s}, 2 \mathrm{H}, \mathrm{D}_{2} \mathrm{O}\right.$ exchangable, $\left.-\mathrm{SO}_{2} \mathrm{NH}_{2}\right), 7.35(\mathrm{~d}, J=4.8 \mathrm{~Hz}, 1 \mathrm{H}$, furan-H), 7.49-7.61 (m, 4H, Ar-H), 7.65 (d, J=8.6 Hz, 2H, Ar-H), 7.86 $(\mathrm{d}, J=7.3 \mathrm{~Hz}, 2 \mathrm{H}, \mathrm{Ar}-\mathrm{H}), 10.06\left(\mathrm{~s}, 1 \mathrm{H}, \mathrm{D}_{2} \mathrm{O}\right.$ exchangable, $\left.-\mathrm{NH}\right) ;{ }^{13} \mathrm{C}$ 
NMR (DMSO- $\left.d_{6}\right) \delta$ ppm: $53.32\left(\mathrm{CH}_{2}\right), 112.53,126.85,127.26,127.76$, 127.84, 128.53, 129.47, 129.64, 134.60, 135.15, 139.52, 143.43, 147.35; Anal. Calcd. for $\mathrm{C}_{18} \mathrm{H}_{17} \mathrm{~N}_{3} \mathrm{O}_{5} \mathrm{~S}_{2}$ (419.47): C, 51.54; H, 4.08; N, 10.02; Found C, 51.71; H, 3.89; N, 10.35 .

5.1.2.9. 4-[2-(1-(Benzofuran-2-yl)-2-(phenylsulfonyl)ethylidene) hydrazinyl] benzenesulfonamide (4i). White crystals, (yield $72 \%$ ), $\mathrm{m}$. p. $244-246{ }^{\circ} \mathrm{C}$; IR $\left(\mathrm{KBr}, \nu_{\max } / \mathrm{cm}^{-1}\right)$ : 3383, 3321, $3259\left(\mathrm{NH}_{2} \& \mathrm{NH}\right)$, 1334 and $1153\left(\mathrm{SO}_{2}\right) ;{ }^{1} \mathrm{H}$ NMR (DMSO- $\left.d_{6}\right) \delta$ ppm: $4.81 \& 5.17(\mathrm{~s}, 2 \mathrm{H}$, $-\mathrm{SO}_{2} \mathrm{CH}_{2^{-}}, Z \& E$ isomers), $6.97(\mathrm{~d}, J=8.7 \mathrm{~Hz}, 1 \mathrm{H}$, Furan-H), 7.10-7.16 $\left(\mathrm{m}, 3 \mathrm{H}, \mathrm{Ar}-\mathrm{H}\right.$ and $\mathrm{D}_{2} \mathrm{O}$ exchangable, $\left.-\mathrm{SO}_{2} \mathrm{NH}_{2}\right), 7.20-7.37(\mathrm{~m}, 2 \mathrm{H}, \mathrm{Ar}-$ $\mathrm{H}), 7.50-7.65(\mathrm{~m}, 3 \mathrm{H}, \mathrm{Ar}-\mathrm{H}), 7.72-7.76(\mathrm{~m}, 3 \mathrm{H}, \mathrm{Ar}-\mathrm{H}), 7.87$ (d, $J=7.4 \mathrm{~Hz}, 2 \mathrm{H}, \mathrm{Ar}-\mathrm{H}$ ), 7.92 (d, $J=6.2 \mathrm{~Hz}, 2 \mathrm{H}, \mathrm{Ar}-\mathrm{H}), 10.35 \& 10.57$ (s, $1 \mathrm{H}, \mathrm{D}_{2} \mathrm{O}$ exchangable, $-\mathrm{NH}, \mathrm{Z} \& \mathrm{E}$ isomers); ${ }^{13} \mathrm{C}$ NMR (DMSO- $d_{6}$ ) $\delta$ ppm: $52.39\left(\mathrm{CH}_{2}\right), 112.76,113.74,126.73,127.00,127.13,127.43$, $127.71,128.04,128.70,129.42,129.47,132.26,134.44,135.16,136.66$, $136.80,139.72,139.90,140.01,147.70,148.86$; Anal. Calcd. for $\mathrm{C}_{22} \mathrm{H}_{19} \mathrm{~N}_{3} \mathrm{O}_{5} \mathrm{~S}_{2}$ (469.53): C, 56.28; $\mathrm{H}, 4.08 ; \mathrm{N}, 8.95 ;$ Found $\mathrm{C}, 56.01 ; \mathrm{H}$, 4.19; N, 9.17.

5.1.2.10. 4-[2-(1-Phenyl-2-tosylethylidene)hydrazinyl]benzenesulfonamide (4j). Buff crystals, (yield $83 \%)$, m. p. $223-224^{\circ} \mathrm{C}$; IR $(\mathrm{KBr}$, $\left.\nu_{\text {max }} / \mathrm{cm}^{-1}\right)$ : 3375, 3325, $3267\left(\mathrm{NH}_{2} \& \mathrm{NH}\right), 1342$ and $1153\left(\mathrm{SO}_{2}\right) ;{ }^{1} \mathrm{H}$ NMR (DMSO-d $\left.d_{6}\right) \delta$ ppm: $2.22\left(\mathrm{~s}, 3 \mathrm{H}, \mathrm{CH}_{3}\right), 5.16\left(\mathrm{~s}, 2 \mathrm{H},-\mathrm{SO}_{2} \mathrm{CH}_{2}-\right), 7.12$ (s, $2 \mathrm{H}, \mathrm{D}_{2} \mathrm{O}$ exchangable, $\left.-\mathrm{SO}_{2} \mathrm{NH}_{2}\right), 7.16(\mathrm{~d}, J=8.8 \mathrm{~Hz}, 2 \overline{\mathrm{H}}, \mathrm{Ar}-\mathrm{H})$, 7.27-7.34 (m, 5H, Ar-H), 7.67 (d, $J=8.8 \mathrm{~Hz}, 2 \mathrm{H}, \mathrm{Ar}-\mathrm{H}), 7.71-7.75$ $(\mathrm{m}, 4 \mathrm{H}, \mathrm{Ar}-\mathrm{H})), 10.01$ (s, $1 \mathrm{H}, \mathrm{D}_{2} \mathrm{O}$ exchangable, $\left.-\mathrm{NH}\right) ;{ }^{13} \mathrm{C}$ NMR (DMSO-d $\left.d_{6}\right) \delta$ ppm: $21.42\left(\underline{\mathrm{CH}}_{3}\right), 52.57\left(\underline{\mathrm{CH}}_{2}\right), 112.66,126.56,127.12$, 127.64, 128.36, 129.37, 129.97, 132.88, 135.04, 136.70, 137.66, 145.20, 147.63; Anal. Calcd. for $\mathrm{C}_{21} \mathrm{H}_{21} \mathrm{~N}_{3} \mathrm{O}_{4} \mathrm{~S}_{2}$ (443.54): C, 56.87; $\mathrm{H}, 4.77 ; \mathrm{N}$, 9.47; Found C, 57.14; H, 4.90; N, 9.68.

5.1.2.11. 4-[2-(1-(4-Fluorophenyl)-2-tosylethylidene)hydrazinyl]benzenesulfonamide (4k). White crystals, (yield 66\%), m. p. 238-240 ${ }^{\circ} \mathrm{C}$; IR $\left(\mathrm{KBr}, \nu_{\max } / \mathrm{cm}^{-1}\right): 3375,3325,3263\left(\mathrm{NH}_{2} \& \mathrm{NH}\right)$, 1327 and $1153\left(\mathrm{SO}_{2}\right) ;{ }^{1} \mathrm{H}$ NMR (DMSO-d $\left.d_{6}\right) \delta$ ppm: $2.23\left(\mathrm{~s}, 3 \mathrm{H}, \mathrm{CH}_{3}\right)$, $5.16\left(\mathrm{~s}, 2 \mathrm{H},-\mathrm{SO}_{2} \mathrm{CH}_{2^{-}}\right), 7.11\left(\mathrm{~s}, 2 \mathrm{H}, \mathrm{D}_{2} \mathrm{O}\right.$ exchangable, $\left.-\mathrm{SO}_{2} \mathrm{NH}_{2}\right)$, 7.13-7.16 (m, 4H, Ar-H), 7.29 (d, J=8.0 Hz, 2H, Ar-H), 7.67 (d, $J=8.8 \mathrm{~Hz}, 2 \mathrm{H}, \mathrm{Ar}-\mathrm{H}), 7.71(\mathrm{~d}, J=8.2,2 \mathrm{H}, \mathrm{Ar}-\mathrm{H}), 7.75-7.79(\mathrm{~m}, 2 \mathrm{H}, \mathrm{Ar}-$ $\mathrm{H}), 9.98\left(\mathrm{~s}, 1 \mathrm{H}, \mathrm{D}_{2} \mathrm{O}\right.$ exchangable, $\left.-\mathrm{NH}\right) ;{ }^{13} \mathrm{C}$ NMR (DMSO-d $\left.{ }_{6}\right) \delta \mathrm{ppm}$ : $21.40\left(\mathrm{CH}_{3}\right), 52.62\left(\mathrm{CH}_{2}\right), 112.65,115.44,127.64,128.64,129.85$, $132.05,134.23,135.05,136.62,145.26,147.59,161.26,163.70$; ESI MS $m / z: 461[\mathrm{M}]^{+}, 462[\mathrm{M}+1]^{+}$; Anal. Calcd. for $\mathrm{C}_{21} \mathrm{H}_{20} \mathrm{FN}_{3} \mathrm{O}_{4} \mathrm{~S}_{2}$ (461.53): C, 54.65; H, 4.37; N, 9.10; Found C, 55.02; H, 4.51; N, 9.38.

5.1.2.12. 4-[2-(1-(4-Chlorophenyl)-2-tosylethylidene)hydrazinyl]benzenesulfonamide (4l). White crystals, (yield 72\%), m. p. 222-223 ${ }^{\circ} \mathrm{C}$; IR $\left(\mathrm{KBr}, \nu_{\max } / \mathrm{cm}^{-1}\right): 3360,3329,3263\left(\mathrm{NH}_{2} \& \mathrm{NH}\right), 1334$ and 1149 $\left(\mathrm{SO}_{2}\right) ;{ }^{1} \mathrm{H}$ NMR (DMSO-d $\left.d_{6}\right) \delta$ ppm: $2.23\left(\mathrm{~s}, 3 \mathrm{H}, \mathrm{CH}_{3}\right), 5.16(\mathrm{~s}, 2 \mathrm{H}$, $\left.-\mathrm{SO}_{2} \mathrm{CH}_{2}-\right), 7.13\left(\mathrm{~s}, 2 \mathrm{H}, \mathrm{D}_{2} \mathrm{O}\right.$ exchangable, $\left.-\mathrm{SO}_{2} \mathrm{NH}_{2}\right), 7.16(\mathrm{~d}$, $J=8.8 \mathrm{~Hz}, 2 \mathrm{H}, \mathrm{Ar}-\mathrm{H}), 7.28$ (d, $J=8.0 \mathrm{~Hz}, 2 \mathrm{H}, \mathrm{Ar}-\mathrm{H}), 7.35(\mathrm{~d}, J=8.6 \mathrm{~Hz}$, $2 \mathrm{H}, \mathrm{Ar}-\mathrm{H}), 7.67-7.75(\mathrm{~m}, 6 \mathrm{H}, \mathrm{Ar}-\mathrm{H}), 10.05$ (s, $1 \mathrm{H}, \mathrm{D}_{2} \mathrm{O}$ exchangable, -NH); ${ }^{13} \mathrm{C}$ NMR (DMSO-d $\left.d_{6}\right) \delta$ ppm: $21.26\left(\mathrm{CH}_{3}\right), 52.40\left(\mathrm{CH}_{2}\right), 112.83$, 127.62, 128.14, 128.58, 130.02, 131.86, 133. $\overline{2} 6,134.40,135.82,136.24$, 145.89; Anal. Calcd. for $\mathrm{C}_{21} \mathrm{H}_{20} \mathrm{ClN}_{3} \mathrm{O}_{4} \mathrm{~S}_{2}$ (477.98): C, 52.77; $\mathrm{H}, 4.22$; 7.42; N, 8.79; Found C, 53.04; H, 4.07; N, 9.16.

5.1.2.13. 4-[2-(1-(4-Bromophenyl)-2-tosylethylidene)hydrazinyl]benzenesulfonamide (4m). White crystals, (yield $81 \%$ ), m. p. 248-249 ${ }^{\circ} \mathrm{C}$; IR $\left(\mathrm{KBr}, \nu_{\max } / \mathrm{cm}^{-1}\right): 3371,3321,3267\left(\mathrm{NH}_{2} \& \mathrm{NH}\right), 1338$ and $1153\left(\mathrm{SO}_{2}\right) ;{ }^{1} \mathrm{H}$ NMR (DMSO-d $\left.{ }_{6}\right) \delta$ ppm: $2.23\left(\mathrm{~s}, 3 \mathrm{H}, \mathrm{CH}_{3}\right), 5.15(\mathrm{~s}$, $\left.2 \mathrm{H},-\mathrm{SO}_{2} \mathrm{CH}_{2}-\right), 7.13\left(\mathrm{~s}, 2 \mathrm{H}, \mathrm{D}_{2} \mathrm{O}\right.$ exchangable, $\left.-\mathrm{SO}_{2} \mathrm{NH}_{2}\right), 7.16$ (d, $J=8.8 \mathrm{~Hz}, \overline{2} \mathrm{H}, \mathrm{Ar}-\mathrm{H}), 7.28(\mathrm{~d}, J=8.1 \mathrm{~Hz}, 2 \mathrm{H}, \mathrm{Ar}-\mathrm{H}), 7.48(\mathrm{~d}, J=8.6 \mathrm{~Hz}$, $2 \mathrm{H}, \mathrm{Ar}-\mathrm{H}), 7.66-7.70(\mathrm{~m}, 6 \mathrm{H}, \mathrm{Ar}-\mathrm{H}), 10.06\left(\mathrm{~s}, 1 \mathrm{H}, \mathrm{D}_{2} \mathrm{O}\right.$ exchangable, -NH); ${ }^{13} \mathrm{C}$ NMR (DMSO-d $\left.{ }_{6}\right) \delta$ ppm: $21.26\left(\underline{\mathrm{CH}}_{3}\right), 52.33\left(\underline{\mathrm{CH}}_{2}\right), 112.85$,
121.89, 127.62, 128.39, 128.56, 130.02, 131.49, 131.93, 134.32, 135.71, 136.57, 145.92, 147.39; ESI MS m/z: $523[\mathrm{M}+1]^{+}, 524[\mathrm{M}+2]^{+}$; Anal. Calcd. for $\mathrm{C}_{21} \mathrm{H}_{20} \mathrm{BrN}_{3} \mathrm{O}_{4} \mathrm{~S}_{2}$ (522.44): C, 48.28; $\mathrm{H}, 3.86$; N, 8.04; Found C, 48.69; H, 4.01; N, 8.37.

5.1.2.14. 4-[2-(1-(p-Tolyl)-2-tosylethylidene)hydrazinyl]benzenesulfonamide (4n). White crystals, (yield 65\%), m. p. $224-225^{\circ} \mathrm{C}$; IR $\left(\mathrm{KBr}, \nu_{\max } / \mathrm{cm}^{-1}\right): 3383,3325,3275\left(\mathrm{NH}_{2} \& \mathrm{NH}\right), 1342$ and 1149 $\left(\mathrm{SO}_{2}\right) ;{ }^{1} \mathrm{H}$ NMR (DMSO-d $\left.\mathrm{d}_{6}\right) \delta$ ppm: $2.23\left(\mathrm{~s}, 3 \mathrm{H}, \mathrm{CH}_{3}\right), 2.31(\mathrm{~s}, 3 \mathrm{H}$, $\left.-\mathrm{CH}_{3}\right), 5.11\left(\mathrm{~s}, 2 \mathrm{H},-\mathrm{SO}_{2} \mathrm{CH}_{2}{ }^{-}\right), 7.11\left(\mathrm{~s}, 2 \mathrm{H}, \mathrm{D}_{2} \mathrm{O}\right.$ exchangable, $\mathrm{SO}_{2} \mathrm{NH}_{2}$ ), 7.12-7.14 (m, 4H, $\left.\mathrm{Ar}-\mathrm{H}\right), 7.28$ (d, $\left.J=8.1 \mathrm{~Hz}, 2 \mathrm{H}, \mathrm{Ar}-\mathrm{H}\right), 7.63$ (d, $J=8.2 \mathrm{~Hz}, 2 \mathrm{H}, \operatorname{Ar}-\mathrm{H}), 7.66(\mathrm{~d}, J=8.7 \mathrm{~Hz}, 2 \mathrm{H}, A r-\mathrm{H}), 7.71$ (d, $J=8.2 \mathrm{~Hz}, 2 \mathrm{H}, \mathrm{Ar}-\mathrm{H}), 9.89$ (s, $1 \mathrm{H}, \mathrm{D}_{2} \mathrm{O}$ exchangable, $\left.-\mathrm{NH}\right) ;{ }^{13} \mathrm{C}$ NMR (DMSO- $\left.d_{6}\right) \delta$ ppm: 21.05, $21.25\left(2 \mathrm{CH}_{3}\right), 52.55\left(\mathrm{CH}_{2}\right), 112.59,126.42$, 127.58, 128.49, 129.31, 129.99, 133.29, 134.59, 135.92, 138.48, 145.79, 147.64; Anal. Calcd. for $\mathrm{C}_{22} \mathrm{H}_{23} \mathrm{~N}_{3} \mathrm{O}_{4} \mathrm{~S}_{2}$ (457.57): C, 57.75; $\mathrm{H}, 5.07 ; \mathrm{N}$, 9.18; Found C, 58.02; H, 4.95; N, 9.44.

5.1.2.15. 4-[2-(1-(4-Nitrophenyl)-2-tosylethylidene)hydrazinyl]benzenesulfonamide (4o). Yellow crystals, (yield 84\%), m. p. 241-243 ${ }^{\circ} \mathrm{C}$; IR $\left(\mathrm{KBr}, \nu_{\max } / \mathrm{cm}^{-1}\right): 3371,3309,3263\left(\mathrm{NH}_{2} \& \mathrm{NH}\right), 1338$ and $1149\left(\mathrm{SO}_{2}\right) ;{ }^{1} \mathrm{H}$ NMR (DMSO-d $\left.\mathrm{d}_{6}\right) \delta$ ppm: $2.20\left(\mathrm{~s}, 3 \mathrm{H},-\mathrm{CH}_{3}\right), 5.25$ (s, $\left.2 \mathrm{H},-\mathrm{SO}_{2} \mathrm{CH}_{2}-\right), 7.17$ (s, $2 \mathrm{H}, \mathrm{D}_{2} \mathrm{O}$ exchangable, $\left.-\mathrm{SO}_{2} \mathrm{NH}_{2}\right), 7.24$ (d, $J=8.8 \mathrm{~Hz}, 2 \mathrm{H}, \mathrm{Ar}-\mathrm{H}), 7.28(\mathrm{~d}, J=8.0 \mathrm{~Hz}, 2 \mathrm{H}, \mathrm{Ar}-\mathrm{H}), 7.70-7.73(\mathrm{~m}, 4 \mathrm{H}$, Ar-H), 7.98 (d, $J=9.0,2 \mathrm{H}, \mathrm{Ar}-\mathrm{H}), 8.13(\mathrm{~d}, J=9.0 \mathrm{~Hz}, 2 \mathrm{H}, \mathrm{Ar}-\mathrm{H}), 10.36$ $\left(\mathrm{s}, 1 \mathrm{H}, \mathrm{D}_{2} \mathrm{O}\right.$ exchangable, $\left.-\mathrm{NH}\right) ;{ }^{13} \mathrm{C}$ NMR (DMSO- $\left.d_{6}\right) \delta$ ppm: 21.35 $\left(\mathrm{CH}_{3}\right), 52.29\left(\mathrm{CH}_{2}\right), 113.31,123.67,127.33,128.57,129.91,130.18$, 130.93, 136.13, 136.44, 144.05, 145.45, 146.70, 146.97; Anal. Calcd. for $\mathrm{C}_{21} \mathrm{H}_{20} \mathrm{~N}_{4} \mathrm{O}_{6} \mathrm{~S}_{2}$ (488.54): C, 51.63; H, 4.13; N, 11.47; Found $\mathrm{C}$, 51.49; H, 4.29; N, 11.73 .

5.1.2.16. 4-[2-(1-(Naphthalen-2-yl)-2-tosylethylidene)hydrazinyl] benzenesulfonamide (4p). White crystals, (yield 66\%), m. p. 226-227 ${ }^{\circ} \mathrm{C}$; IR ( $\left.\mathrm{KBr}, \nu_{\max } / \mathrm{cm}^{-1}\right)$ : 3387, 3329, $3263\left(\mathrm{NH}_{2} \& \mathrm{NH}\right), 1323$ and $1153\left(\mathrm{SO}_{2}\right) ;{ }^{1} \mathrm{H}$ NMR (DMSO- $\left.d_{6}\right) \delta$ ppm: $2.06\left(\mathrm{~s}, 3 \mathrm{H},-\mathrm{CH}_{3}\right), 5.28$ (s, $\left.2 \mathrm{H},-\mathrm{SO}_{2} \mathrm{CH}_{2}-\right), 7.14\left(\mathrm{~s}, 2 \mathrm{H}, \mathrm{D}_{2} \mathrm{O}\right.$ exchangable, $\left.-\mathrm{SO}_{2} \mathrm{NH}_{2}\right), 7.19$ (d, $J=8.0 \mathrm{~Hz}, 2 \mathrm{H}, \mathrm{Ar}-\mathrm{H}), 7.25$ (d, $J=8.8 \mathrm{~Hz}, 2 \mathrm{H}, \mathrm{Ar}-\mathrm{H}), 7.49-7.52(\mathrm{~m}, 2 \mathrm{H}$, Ar-H), 7.71 (d, $J=8.5 \mathrm{~Hz}, 4 \mathrm{H}, \mathrm{Ar}-\mathrm{H}), 7.78-7.80(\mathrm{~m}, 1 \mathrm{H}, \mathrm{Ar}-\mathrm{H}), 7.83$ (d, $J=8.4 \mathrm{~Hz}, 1 \mathrm{H}, \mathrm{Ar}-\mathrm{H}), 7.86-7.88(\mathrm{~m}, 1 \mathrm{H}, \mathrm{Ar}-\mathrm{H}), 7.99(\mathrm{~s}, 1 \mathrm{H}, \mathrm{Ar}-\mathrm{H})$, 8.04-8.07 (m, 1H, Ar-H), $10.13\left(\mathrm{~s}, 1 \mathrm{H}, \mathrm{D}_{2} \mathrm{O}\right.$ exchangable, $\left.-\mathrm{NH}\right) ;{ }^{13} \mathrm{C}$ NMR (DMSO-d $\left.d_{6}\right) \delta$ ppm: $21.24\left(\mathrm{CH}_{3}\right), 52.52\left(\underline{\mathrm{CH}}_{2}\right), 112.80,113.78$, 122.27, 124.13, 126.15, 126.66, 127.41, 127.95, 128.75, 129.77, 132.84, 133.13, 134.96, 136.69, 145.16, 147.69, 148.81; Anal. Calcd. for $\mathrm{C}_{25} \mathrm{H}_{23} \mathrm{~N}_{3} \mathrm{O}_{4} \mathrm{~S}_{2}$ (493.6): C, 60.83; H, 4.70; N, 8.51; Found C, 61.18; H, $4.89 ; \mathrm{N}, 8.24$.

5.1.2.17. 4-(2-(1-(2-Thienyl)-2-tosylethylidene)hydrazinyl)benzenesulfonamide (4q). Grey crystals, (yield $75 \%$ ), m. p. $231-233^{\circ} \mathrm{C}$; IR $\left(\mathrm{KBr}, \nu_{\max } / \mathrm{cm}^{-1}\right): 3360,3332,3267\left(\mathrm{NH}_{2} \& \mathrm{NH}\right), 1338$ and 1149 (SO2); ${ }^{1} \mathrm{H}$ NMR (DMSO- $\left.d_{6}\right) \delta$ ppm: $2.24\left(\mathrm{~s}, 3 \mathrm{H},-\mathrm{CH}_{3}\right), 5.12(\mathrm{~s}, 2 \mathrm{H},-$ $\left.\mathrm{SO}_{2} \mathrm{CH}_{2}-\right), 7.02(\mathrm{~d}, J=8.7 \mathrm{~Hz}, 2 \mathrm{H}, \mathrm{Ar}-\mathrm{H}), 7.11\left(\mathrm{~s}, 2 \mathrm{H}, \overline{\mathrm{D}}_{2} \mathrm{O}\right.$ exchangable, - $\left.\mathrm{SO}_{2} \mathrm{NH}_{2}\right), 7.19(\mathrm{t}, J=4.4 \mathrm{~Hz}, 1 \mathrm{H}, \mathrm{H}$-thiophene), $7.27(\mathrm{~d}, J=8.1 \mathrm{~Hz}$, $2 \mathrm{H}, \mathrm{Ar}-\mathrm{H}$ ), 7.36 (d, $J=5.0 \mathrm{~Hz}, 1 \mathrm{H}, \mathrm{H}$-thiophene), $7.63(\mathrm{~d}, J=8.8 \mathrm{~Hz}$, 2H, Ar-H), 7.70 (d, J=8.1 Hz, 2H, Ar-H), 7.99 (d, $J=4.8 \mathrm{~Hz}, 1 \mathrm{H}, \mathrm{H}-$ thiophene), 9.99 (s, 1H, $\mathrm{D}_{2} \mathrm{O}$ exchangable, $\left.-\mathrm{NH}\right) ;{ }^{13} \mathrm{C}$ NMR (DMSO$\left.d_{6}\right) \delta$ ppm: $21.44\left(\mathrm{CH}_{3}\right), 53.51\left(\mathrm{CH}_{2}\right), 112.45,126.93,127.24,127.65$, 127.84, 128.77, 129.87, 129.98, 135.01, 136.58, 143.47, 145.32, 147.27; Anal. Calcd. for $\mathrm{C}_{19} \mathrm{H}_{19} \mathrm{~N}_{3} \mathrm{O}_{4} \mathrm{~S}_{3}$ (449.57): C, 50.76; $\mathrm{H}, 4.26$; N, 9.35; Found C, 50.91; H, 4.50; N, 9.66.

\subsection{Biological evaluation}

\subsubsection{Carbonic anhydrase inhibition}

An Applied Photophysics stopped-flow instrument has been used for assaying the CA catalysed $\mathrm{CO}_{2}$ hydration activity [18]. 
Phenol red (at a concentration of $0.2 \mu \mathrm{M}$ ) has been used as indicator, working at the absorbance maximum of $557 \mathrm{~nm}$, with $20 \mu \mathrm{M}$ Hepes (pH 7.5) as buffer, and $20 \mu \mathrm{M} \mathrm{Na}_{2} \mathrm{SO}_{4}$ (for maintaining constant the ionic strength), following the initial rates of the CAcatalyzed $\mathrm{CO}_{2}$ hydration reaction for a period of $10-100 \mathrm{~s}$. The $\mathrm{CO}_{2}$ concentrations ranged from 1.7 to $17 \mu \mathrm{M}$ for the determination of the kinetic parameters and inhibition constants. For each inhibitor at least six traces of the initial $5-10 \%$ of the reaction have been used for determining the initial velocity. The un-catalysed rates were determined in the same manner and subtracted from the total observed rates. Stock solutions of the inhibitor $(0.1 \mu \mathrm{M})$ were prepared in distilled-deionized water and dilutions up to $0.01 \mathrm{nM}$ were done thereafter with the assay buffer. Inhibitor and enzyme solutions were pre-incubated together for $15 \mathrm{~min}$ at room temperature prior to assay, in order to allow for the formation of the E-I complex. The inhibition constants were obtained by nonlinear least-squares methods using PRISM 3 and the Cheng-Prusoff equation, as reported earlier [29-32]. and represent the mean from at least three different determinations. All CA isoforms were recombinant ones obtained in-house as reported earlier [33-35].

\subsubsection{In vitro cytotoxic assay}

MCF-7 and MDA-MB-231 cancer cell lines were obtained from the American wild type collection. Incubation of the cells was done under hypoxic conditions of $5 \% \mathrm{CO}_{2}$, all other procedures regarding the assay was done using MTT assay as reported [36].

\subsection{Computational studies}

5LJT (hCA II) [21] and 5FL4 (hCA IX) [22] crystal structures were prepared according to the Protein Preparation module in Maestro Schrödinger suite, assigning bond orders, adding hydrogens, deleting water molecules, and optimizing H-bonding networks. Finally, energy minimization with a root mean square deviation (RMSD) value of 0.30 was applied using an Optimized Potentials for Liquid Simulation (OPLS_2005) force field [37]. 3D ligand structures were prepared by Maestro, evaluated for their ionization states at $\mathrm{pH} 7.4 \pm 0.5$ with Epik OPLS-2005 force field in Macromodel was used for energy minimization for a maximum number of 2500 conjugate gradient iterations and setting a convergence criterion of $0.05 \mathrm{kcal} \mathrm{mol}^{-1} \AA^{-1}$. Grids for docking were centered in the centroid of the complexed ligand. Flexible docking studies were carried out with the program Glide, using the standard precision (SP) mode, turning on the sampling of ring conformation option and the postdocking minimization. The best scored docking poses were selected and passed onto Prime for refinement with the VSGB continuum solvent model [38].

\section{Appendix A. Supplementary data}

Supplementary data related to this article can be found at https://doi.org/10.1016/j.ejmech.2018.04.016.

\section{References}

[1] D. Neri, C.T. Supuran, Interfering with pH regulation in tumours as a therapeutic strategy, Nat. Rev. Drug Discov. 10 (2011) 767.

[2] G. De Simone, C.T. Supuran, Carbonic anhydrase IX: biochemical and crystallographic characterization of a novel antitumor target, Biochim. Biophys. Acta Protein Proteonomics 1804 (2010) 404-409.

[3] J. Pastorek, S. Pastorekova, Hypoxia-induced carbonic anhydrase IX as a target for cancer therapy: from biology to clinical use, in: Seminars in Cancer Biology, Elsevier, 2015, pp. 52-64.

[4] F. Pacchiano, F. Carta, P.C. McDonald, Y. Lou, D. Vullo, A. Scozzafava, S. Dedhar, C.T. Supuran, Ureido-substituted benzenesulfonamides potently inhibit carbonic anhydrase IX and show antimetastatic activity in a model of breast cancer metastasis, J. Med. Chem. 54 (2011) 1896-1902.

[5] R.G. Gieling, M. Babur, L. Mamnani, N. Burrows, B.A. Telfer, F. Carta, J.Y. Winum, A. Scozzafava, C.T. Supuran, K.J. Williams, Antimetastatic effect of sulfamate carbonic anhydrase IX inhibitors in breast carcinoma xenografts J. Med. Chem. 55 (2012) 5591-5600.

[6] C.T. Supuran, Carbonic anhydrase inhibition and the management of hypoxic tumors, Metabolites 7 (2017) 48.

[7] C.T. Supuran, Carbonic anhydrases: novel therapeutic applications for in hibitors and activators, Nat. Rev. Drug Discov. 7 (2008) 168-181.

[8] V. Alterio, A. Di Fiore, K. D'Ambrosio, C.T. Supuran, G. De Simone, Multiple binding modes of inhibitors to carbonic anhydrases: how to design specific drugs targeting 15 different isoforms? Chem. Rev. 112 (2012) 4421-4468.

[9] C.T. Supuran, How many carbonic anhydrase inhibition mechanisms exist? J. Enzym. Inhib. Med. Chem. (2015) 1-16.

[10] A. Nocentini, S. Bua, C.L. Lomelino, R. McKenna, M. Menicatti, G. Bartolucci, B. Tenci, L. Di Cesare Mannelli, C. Ghelardini, P. Gratteri, Discovery of new sulfonamide carbonic anhydrase IX inhibitors incorporating nitrogenous bases, ACS Med. Chem. Lett. 8 (2017) 1314-1319.

[11] M. Bozdag, M. Ferraroni, E. Nuti, D. Vullo, A. Rossello, F. Carta, A. Scozzafava, C.T. Supuran, Combining the tail and the ring approaches for obtaining potent and isoform-selective carbonic anhydrase inhibitors: solution and X-ray crystallographic studies, Bioorg. Med. Chem. 22 (2014) 334-340.

[12] U.N.I.o. Health, ClinicalTrials. gov. https://clinicaltrialsgov/ct2/ showNCT02767505, 2016

[13] R.P. Tanpure, B. Ren, T.S. Peat, L.F. Bornaghi, D. Vullo, C.T. Supuran, S. A. Poulsen, Carbonic anhydrase inhibitors with dual-tail moieties to match the hydrophobic and hydrophilic halves of the carbonic anhydrase active site, J. Med. Chem. 58 (2015) 1494-1501.

[14] H.A. Abdel-Aziz, K.A. Al-Rashood, K.E.H. ElTahir, G.M. Suddek, Synthesis of Nbenzenesulfonamide-1H-pyrazoles bearing arylsulfonyl moiety: novel celecoxib analogs as potent anti-inflammatory agents, Eur. J. Med. Chem. 80 (2014) 416-422.

[15] H.A. Abdel-Aziz, H.A. Ghabbour, K.A. Al-Rashood, H.-K. Fun, Synthesis and XRay Structure of (1Z, 2Z)-1, 2-Bis (2-(phenylsulfonyl)-1-(4-tolyl) ethylidene) hydrazine, J. Chem. 2014 (2014). Article ID 929401.

[16] H.A. Abdel-Aziz, A.A. Mekawey, Stereoselective synthesis and antimicrobia activity of benzofuran-based (1E)-1-(piperidin-1-yl)-N 2-arylamidrazones, Eur. J. Med. Chem. 44 (2009) 4985-4997.

[17] E. Wyrzykiewicz, D. Prukała, New isomeric N-substituted hydrazones of 2-, 3 and 4-pyridinecarboxaldehydes, J. Het. Chem. 35 (1998) 381-387.

[18] R.G. Khalifah, The carbon dioxide hydration activity of carbonic anhydrase I Stop-flow kinetic studies on the native human isoenzymes B and C, J. Biol. Chem. 246 (1971) 2561-2573.

[19] L. Ivanova, E. Zandberga, K. Silina, Z. Kalnina, A. Ābols, E. Endzelinš, I. Vendina, N. Romanchikova, A. Hegmane, P. Trapencieris, Prognostic relevance of carbonic anhydrase IX expression is distinct in various subtypes of breast cance and its silencing suppresses self-renewal capacity of breast cancer cells, Canc. Chemother. Pharmacol. 75 (2015) 235-246.

[20] Y. Li, H. Wang, E. Oosterwijk, C. Tu, K.T. Shiverick, D.N. Silverman, S.C. Frost, Expression and activity of carbonic anhydrase IX is associated with metabolic dysfunction in MDA-MB-231 breast cancer cells, Canc. Invest. 27 (2009) 613-623.

[21] A. Nocentini, M. Ferraroni, F. Carta, M. Ceruso, P. Gratteri, C. Lanzi, E. Masini C.T. Supuran, Benzenesulfonamides incorporating flexible triazole moieties are highly effective carbonic anhydrase inhibitors: synthesis and kinetic crystallographic, computational, and intraocular pressure lowering investigations, J. Med. Chem. 59 (2016) 10692-10704.

[22] J. Leitans, A. Kazaks, A. Balode, J. Ivanova, R. Zalubovskis, C.T. Supuran, K. Tars, Efficient expression and crystallization system of cancer-associated carbonic anhydrase isoform IX, J. Med. Chem. 58 (2015) 9004-9009.

[23] D. Enders, A. Grossmann, H. Huang, G. Raabe, Dual secondary amine/Nheterocyclic carbene catalysis in the asymmetric michael/cross-benzoin cascade reaction of $\beta$-oxo sulfones with enals, Eur. J. Org Chem. 2011 (2011) 4298-4301.

[24] M. Fares, M.A. Said, M.A. Alsherbiny, R.A. Eladwy, H. Almahli, M.M. Abdel-Aziz, H.A. Ghabbour, W.M. Eldehna, H.A. Abdel-Aziz, Synthesis, biological evaluation and molecular docking of certain sulfones as potential nonazole antifungal agents, Molecules 21 (2016) 114.

[25] H.A. Ghabbour, M.M. Qabeel, W.M. Eldehna, A. Al-Dhfyan, H.A. Abdel-Aziz Design, synthesis, and molecular docking of 1-(1-(4-chlorophenyl)-2-(phenylsulfonyl) ethylidene)-2-phenylhydrazine as potent nonazole anticandida agent, J. Chem. 2014 (2014).

[26] A. Kumar, M.K. Muthyala, 1-Butyl-3-methylimidazolium p-toluenesulfinate: a novel reagent for synthesis of sulfones and $\beta$-ketosulfones in ionic liquid, Tetrahedron Lett. 52 (2011) 5368-5370.

[27] C.-K. Chan, H.-S. Wang, R.-T. Hsu, M.-Y. Chang, Copper triflate mediated $\alpha$ monohalogenation of $\alpha$-diazo $\beta$-ketosulfones with ammonium halides, Synthesis 49 (2017) 2045-2056.

[28] R. Giovannini, M. Petrini, Ruthenium tetroxide catalyzed oxidations of 3-alkyl4-(2-furyl)-4-oxobutanenitriles: synthesis of methyl 2-alkyl-3cyanopropanoates, Tetrahedron Lett. 38 (1997) 3781-3784.

[29] S. Akocak, N. Lolak, A. Nocentini, G. Karakoc, A. Tufan, C.T. Supuran, Synthesis and biological evaluation of novel aromatic and heterocyclic bis-sulfonamide Schiff bases as carbonic anhydrase I, II, VII and IX inhibitors, Bioorg. Med. Chem. 25 (2017) 3093-3097. 
[30] C. Altug, H. Güneş, A. Nocentini, S.M. Monti, M. Buonanno, C.T. Supuran, Synthesis of isoxazole-containing sulfonamides with potent carbonic anhydrase II and VII inhibitory properties, Bioorg. Med. Chem. 25 (2017) 1456-1464.

[31] W.M. Eldehna, M.F. Abo-Ashour, A. Nocentini, P. Gratteri, I.H. Eissa, M. Fares, O.E. Ismael, H.A. Ghabbour, M.M. Elaasser, H.A. Abdel-Aziz, C.T. Supuran, Novel 4/3-((4-oxo-5-(2-oxoindolin-3-ylidene) thiazolidin-2-ylidene) amino) benzenesulfonamides: synthesis, carbonic anhydrase inhibitory activity, anticancer activity and molecular modelling studies, Eur. J. Med. Chem. 139 (2017) 250-262.

[32] H.S. Ibrahim, S.M. Abou-Seri, M. Tanc, M.M. Elaasser, H.A. Abdel-Aziz, C.T. Supuran, Isatin-pyrazole benzenesulfonamide hybrids potently inhibit tumor-associated carbonic anhydrase isoforms IX and XII, Eur. J. Med. Chem. 103 (2015) 583-593.

[33] W.M. Eldehna, G.H. Al-Ansary, S. Bua, A. Nocentini, P. Gratteri, A. Altoukhy H. Ghabbour, H.Y. Ahmed, C.T. Supuran, Novel indolin-2-one-based sulfonamides as carbonic anhydrase inhibitors: synthesis, in vitro biological evaluation against carbonic anhydrases isoforms I, II, IV and VII and molecular docking studies, Eur. J. Med. Chem. 127 (2017) 521-530.

[34] A. Nocentini, R. Cadoni, S. del Prete, C. Capasso, P. Dumy, P. Gratteri, C.T. Supuran, J.-Y. Winum, Benzoxaboroles as efficient inhibitors of the $\beta$ carbonic anhydrases from pathogenic fungi: activity and modeling study, ACS Med. Chem. Lett. 8 (2017) 1194-1198.

[35] Z. Zhang, J. Lau, C. Zhang, N. Colpo, A. Nocentini, C.T. Supuran, F. Benard, K.S. Lin, Design, synthesis and evaluation of $18 \mathrm{~F}-$ labeled cationic carbonic anhydrase IX inhibitors for PET imaging, J. Enzym. Inhib. Med. Chem. 32 (2017) 722-730.

[36] P. Senthilraja, K. Kathiresan, In vitro cytotoxicity MTT assay in Vero, HepG2 and MCF-7 cell lines study of Marine Yeast, J. Appl. Pharmaceut. Sci. 5 (2015) 080-084.

[37] Schrödinger Suite Release 2016-1, Schrödinger, LLC, New York, NY, 2016: (a) Maestro v.10.5;(b) Epik, v.3.5; (c) Impact, v.7.0; (d) Prime, v.4.3; (e) Macromodel v.11.1.(f) Glide, v.7.0.

[38] J. Li, R. Abel, K. Zhu, Y. Cao, S. Zhao, R.A. Friesner, The VSGB 2.0 model: a next generation energy model for high resolution protein structure modeling, Proteins: Struct. Funct. Bioinformatics 79 (2011) 2794-2812. 